\title{
Hydrogen production by Trichodesmium erythraeum Cyanothece sp. and Crocosphaera watsonii
}

\author{
Samuel T. Wilson ${ }^{1,2, *}$, Rachel A. Foster ${ }^{1,3}$, Jonathan P. Zehr ${ }^{1,3}$, David M. Karl ${ }^{1,2}$ \\ ${ }^{1}$ Center for Microbial Oceanography: Research and Education, Honolulu, Hawaii 96822, USA \\ ${ }^{2}$ Department of Oceanography, 1000 Pope Road, University of Hawaii, Honolulu, Hawaii 96822, USA \\ ${ }^{3}$ Ocean Sciences, University of California, Santa Cruz, California 95064, USA
}

\begin{abstract}
Diazotrophic cyanobacteria are important components of marine ecosystems, where they contribute to primary production and provide a source of fixed nitrogen (N). During biological fixation of atmospheric nitrogen $\left(\mathrm{N}_{2}\right)$, hydrogen is produced as an obligate by-product. The present study investigated the potential contribution of 4 marine diazotrophs to the pool of dissolved $\mathrm{H}_{2}$ in the oceans. $\mathrm{N}_{2}$ fixation, as measured by acetylene reduction, and $\mathrm{H}_{2}$ production rates were monitored throughout the diel period in cultures of the filamentous Trichodesmium erythraeum strain IMS101, and the unicellular organisms Cyanothece sp. strain ATCC 51142 and Crocosphaera watsonii strains WH8501 and WH0002. $\mathrm{H}_{2}$ production coincided with diel variations in $\mathrm{N}_{2}$ fixation for each strain regardless of whether $\mathrm{N}_{2}$ fixation peaked during the day or night. Chlorophyll-normalized rates of $\mathrm{H}_{2}$

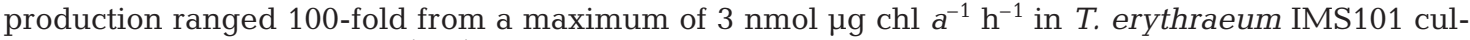

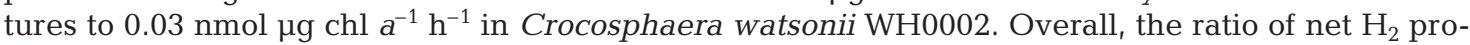
duced to $\mathrm{N}_{2}$ fixed varied from 0.05 to 0.003 in the unicellular cyanobacteria, compared to 0.3 in the filamentous T. erythraeum IMS101, indicating that unicellular cyanobacteria produce less, or alternatively, re-assimilate more of the $\mathrm{H}_{2}$ produced during $\mathrm{N}_{2}$ fixation. Crocosphaera watsonii has recently been identified as a significant source of fixed $\mathrm{N}$ in the marine environment, and an efficient recycling of $\mathrm{H}_{2}$ would provide a valuable source of energy to their respiratory electron transport chain. Furthermore, the magnitude of $\mathrm{H}_{2}$ produced by $T$. erythraeum IMS101 strongly implicates this organism in the production of $\mathrm{H}_{2}$ in the upper ocean.
\end{abstract}

KEY WORDS: $\mathrm{N}_{2}$ fixation $\cdot$ Hydrogen $\cdot$ Cyanobacteria

\section{INTRODUCTION}

The ocean is a net source of hydrogen $\left(\mathrm{H}_{2}\right)$ to the atmosphere (Schmidt 1974, Hauglustaine \& Ehhalt 2002), where it acts as an indirect greenhouse gas by influencing the concentrations of methane in the troposphere and water vapor in the stratosphere (Ehhalt \& Prather 2001). Although the global ocean is typically classified as being 2 to 3 times supersaturated with respect to atmospheric $\mathrm{H}_{2}$ concentrations (Seiler \& Schmidt 1974), the net production of $\mathrm{H}_{2}$ in surface seawater is restricted to tropical and subtropical biomes (Herr et al. 1981). Within the upper water column, vertical profiles of $\mathrm{H}_{2}$ display the highest concentrations within the top $50 \mathrm{~m}$, where values range from 1 to
$3 \mathrm{nmol} \mathrm{l}^{-1}$, followed by sharp decreases in concentration with depth, becoming under-saturated typically within $100 \mathrm{~m}$ of the surface (e.g. Conrad \& Seiler 1988, Moore et al. 2009).

There is conflicting evidence of a diel cycle associated with $\mathrm{H}_{2}$ concentrations in the upper water column of the open ocean. A clear increase during the daytime was reported in the oligotrophic South Atlantic (Herr et al. 1984), compared to a weak daytime peak in the equatorial Atlantic (Conrad \& Seiler 1988), and no diel variation in the California Current System (Setser et al. 1982). The longer-term temporal variability of dissolved $\mathrm{H}_{2}$ concentrations over several months has been reported for high-latitude coastal waters (Punshon et al. 2007). 
The most important environmental parameter influencing ambient $\mathrm{H}_{2}$ concentrations was suggested by Conrad (1988) to be the biological fixation of nitrogen $\left(\mathrm{N}_{2}\right) \cdot \mathrm{H}_{2}$ evolution is an obligate by-product of the enzymatic $\mathrm{N}_{2}$ fixation reaction, summarized in Eq. (1):

$\mathrm{N}_{2}+8 \mathrm{H}^{+}+8 \mathrm{e}^{-}+16 \mathrm{ATP} \rightarrow 2 \mathrm{NH}_{3}+\mathrm{H}_{2}+16 \mathrm{ADP}+16 \mathrm{Pi}$

where $\mathrm{Pi}$ is inorganic phosphate. $\mathrm{H}_{2}$ is formed during the binding of a $\mathrm{N}_{2}$ molecule to the molybdenum-iron (MoFe) subunit of the nitrogenase enzyme complex, prior to the reduction of $\mathrm{N}_{2}$ to ammonia (Lowe \& Thorneley 1984, Howard \& Rees 2006). According to Eq. (1), which represents the least energetically costly stoichiometry for $\mathrm{N}_{2}$ fixation, the theoretical production of $\mathrm{H}_{2}$ under $\mathrm{N}_{2}$-saturating conditions should be equimolar to the rate of $\mathrm{N}_{2}$ fixation (Burns \& Hardy 1975). However, diazotrophs contain uptake hydrogenase, which recycles the $\mathrm{H}_{2}$ produced during $\mathrm{N}_{2}$ fixation, and measured rates of net production of $\mathrm{H}_{2}$ are typically much less than the theoretical maximum (Bothe et al. 1980).

A recent oceanographic cruise across the equatorial Pacific revealed a strong correlation between the rate of $\mathrm{N}_{2}$ fixation and $\mathrm{H}_{2}$ supersaturation (Moore et al. 2009). Further evidence for $\mathrm{N}_{2}$ fixation as the mechanism responsible for dissolved $\mathrm{H}_{2}$ comes from laboratory-based research on photobiological $\mathrm{H}_{2}$ production (reviewed by Asada \& Miyake 1999, Prince \& Kheshgi 2005, Rupprecht et al. 2006). A large and diverse range of microbes have been analyzed for their $\mathrm{H}_{2}$ production rates, and the more extensively examined $\mathrm{N}_{2}$ fixing cyanobacteria include Anabaena sp. (Masukawa et al. 2002), Nostoc punctiforme (Schütz et al. 2004), and Synechococcus sp. (Mitsui \& Suda 1995).

Despite the fact that $\mathrm{N}_{2}$ fixing microorganisms have been studied for their ability to produce $\mathrm{H}_{2}$, it remains unclear how different diazotrophs contribute to dissolved $\mathrm{H}_{2}$ dynamics in the marine environment. The majority of simultaneous measurements of $\mathrm{N}_{2}$ fixation and $\mathrm{H}_{2}$ production in the marine environment have been conducted on Trichodesmium spp., a filamentous non-heterocystous cyanobacterium that fixes $\mathrm{N}_{2}$ during the daytime while evolving oxygen via photosynthesis (Capone et al. 1997). However, results are con- flicting, as laboratory-maintained cultures showed a positive correlation between $\mathrm{H}_{2}$ production and $\mathrm{N}_{2}$ fixation (Punshon \& Moore 2008), yet field-collected colonies showed no correlation with $\mathrm{N}_{2}$ fixation rates (Scranton 1983). Resolving this discrepancy is of particular importance to the marine $\mathrm{H}_{2}$ cycle, given that Trichodesmium spp. is found throughout warm oligotrophic waters and is estimated to contribute 25 to $50 \%$ of the new production in the North Pacific Subtropical Gyre (Karl et al. 1997).

To better understand the role of $\mathrm{N}_{2}$ fixing Cyanobacteria in $\mathrm{H}_{2}$ cycling in the upper ocean, cultures of 3 model marine Cyanobacteria were analyzed for their $\mathrm{N}_{2}$-fixing and $\mathrm{H}_{2}$-production capabilities. The test organisms included Trichodesmium erythraeum strain IMS101, Cyanothece sp. strain ATCC 51142, and Crocosphaera watsonii strains WH8501 and WH0002.

\section{MATERIALS AND METHODS}

Culture conditions. The Cyanobacteria strains used in this work are listed in Table 1 and were grown using fixed N-free media: YBC II medium at $\mathrm{pH} 8.0$ and salinity of 34 for Trichodesmium erythraeum IMS101 (Chen et al. 1996), and SO medium (pH 8.0, salinity 28) (Waterbury \& Willey 1988) for Cyanothece sp. ATCC 51142 and both strains of Crocosphaera watsonii. All cultures were maintained at $26^{\circ} \mathrm{C}$ using a $12: 12 \mathrm{~h}$ square-wave light:dark cycle with a light intensity of $44 \mu \mathrm{mol}$ photons $\mathrm{m}^{-2} \mathrm{~s}^{-1}$. This light intensity is approximately equivalent to a depth of $110 \mathrm{~m}$ at Stn ALOHA. Growth of all cultures was monitored by daily measurements of in vivo fluorescence with a TD-700 Turner Designs fluorometer. Chlorophyll a (chl a) measurements were made at the beginning of each experiment. Triplicate aliquots of cultures were filtered onto $25 \mathrm{~mm}$ Whatman GF/F filters and the chl a extracted in $5 \mathrm{ml}$ of $90 \%$ acetone for $24 \mathrm{~h}$ at $-20^{\circ} \mathrm{C}$ before being analyzed using a Turner Designs Model 10-AU fluorometer (Strickland \& Parsons 1972).

The cultures were grown in $500 \mathrm{ml}$ plastic culture flasks and transferred to borosilicate glass vials for experimental analysis. Typical volumes for sample analysis were $200 \mathrm{ml}$ (for the unicellular diazotrophs)

Table 1. Cyanobacteria strains examined in the present study

\begin{tabular}{|llcl|}
\hline Strain & Location isolated & Year isolated & Source \\
\hline Trichodesmium erythraeum IMS101 & North Carolina coast & 1992 & Prufert-Bebout et al. (1993) \\
Crocosphaera watsonii WH8501 & Tropical South Atlantic & 1984 & Waterbury \& Rippka (1989) \\
Crocosphaera watsonii WH0002 & Hawaii & 2000 & Webb et al. (2009) \\
Cyanothece sp. ATC51142 & Gulf of Mexico & 1993 & Reddy et al. (1993) \\
\hline
\end{tabular}


and $40 \mathrm{ml}$ (for Trichodesmium erythraeum IMS101), which were analyzed in $240 \mathrm{ml}$ and $76 \mathrm{ml}$ glass vials, respectively. The smaller sample volume for $T$. erythraeum IMS101 was due to the magnitude of the $\mathrm{H}_{2}$ produced. The glass vials were crimp-sealed with standard gray butyl rubber stoppers and aluminum seals to ensure the incubations were gas-tight. For each organism, the measurements of $\mathrm{H}_{2}$ and ethylene $\left(\mathrm{C}_{2} \mathrm{H}_{4}\right)$ were run on separate experimental flasks due to the residual $\mathrm{H}_{2}$ in the cylinder of acetylene $\left(\mathrm{C}_{2} \mathrm{H}_{2}\right)$ (Praxair) contaminating the samples and inundating the $\mathrm{H}_{2}$ analyzer.

The analytical method was designed to measure continual rates of acetylene reduction and $\mathrm{H}_{2}$ production in the Cyanobacteria cultures using on-line automated systems (Fig. 1). These 2 systems are described separately below ('Hydrogen measurements' and 'Nitrogenase activity').

Hydrogen measurements. The analytical protocol for $\mathrm{H}_{2}$ analysis was designed to minimize contamination from the ambient atmosphere and sampling equipment. The gray stoppers for the glass vials were pierced with two 1/16 inch (1.6 mm) PEEK tubes (VICI Valco Instruments): an inlet which extended to the base of the flask, and an outlet which reached just inside the crimp-seal. The culture was continually purged with zero- $\mathrm{H}_{2}(<10 \mathrm{ppt})$ air at a flow rate of $5.4 \mathrm{ml} \mathrm{min}^{-1}$. The outlet tubing incorporated a $13 \mathrm{~mm}$ diameter hydrophobic filter to prevent any accidental injections of seawater and passed through a nafion drier (Perma Pure) to remove water vapor. The sample gas stream was connected directly from the nafion drier to the injection port of the reduced gas analyzer. Between each sample analysis, the tubing was disconnected, cleaned and purged with ultra-high-purity air
(Airgas). One unavoidable feature of the analytical setup is the inherent delay in purging the sample of $\mathrm{H}_{2}$; i.e. if $\mathrm{H}_{2}$ production were to cease, this would not be instantly recorded by the analyzer. Controlled measurements showed that it took $45 \mathrm{~min}$ to completely purge $\mathrm{H}_{2}$ from the larger $240 \mathrm{ml}$ glass vial used for the unicellular diazotrophs and $15 \mathrm{~min}$ to purge the $76 \mathrm{ml}$ glass vial used for Trichodesmium erythraeum IMS101.

$\mathrm{H}_{2}$ concentrations were measured using a reduced gas analyzer that incorporated a mercuric oxide bed coupled to a reducing compound photometer (Peak Laboratories). In brief, the reduction of heated mercuric oxide by $\mathrm{H}_{2}$ gas liberated mercury vapor ( $\mathrm{HgO}$ (solid) $+\mathrm{H}_{2} \rightarrow \mathrm{Hg}$ (vapor) $+\mathrm{H}_{2} \mathrm{O}$ ) which was quantitatively detected using an ultraviolet absorption photometer located immediately downstream from the reaction site. The gas flow exiting the detector passed through an activated charcoal mercury scrubber before venting. Samples were injected via a $2 \mathrm{ml}$ sample loop typically every 5 min onto 2 analytical columns maintained at $104^{\circ} \mathrm{C}$. The first column was packed with Unibeads 1S (60/80 mesh, 1/8 inch [3.2 mm] diameter, and 16.5 inch [41.9 cm] length), and the second one with Molecular Sieve 13X (60/80 mesh, $1 / 8$ inch [3.2 mm] diameter, and 81 inch [2.06 m] length). The retention time for $\mathrm{H}_{2}$ was $51 \mathrm{~s}$. The analytical precision based on the comparison of 4 samples was $\pm 2 \%$ and the detection limit was $0.2 \mathrm{nmol}^{-1} \mathrm{~h}^{-1}$, equating to a $\mathrm{H}_{2}$ production rate in our experiments of 3 pmol $(\mu \mathrm{g} \mathrm{chl} a)^{-1} \mathrm{~h}^{-1}$. Blank controls, consisting of filtered autoclaved seawater, never produced $\mathrm{H}_{2}$ above the detection limit. The analyzer was calibrated using a $1 \mathrm{ppm} \mathrm{H}_{2}$ standard (Scott Marrin) and serially diluted using zero- $\mathrm{H}_{2}$ air. Over the experimental period, the

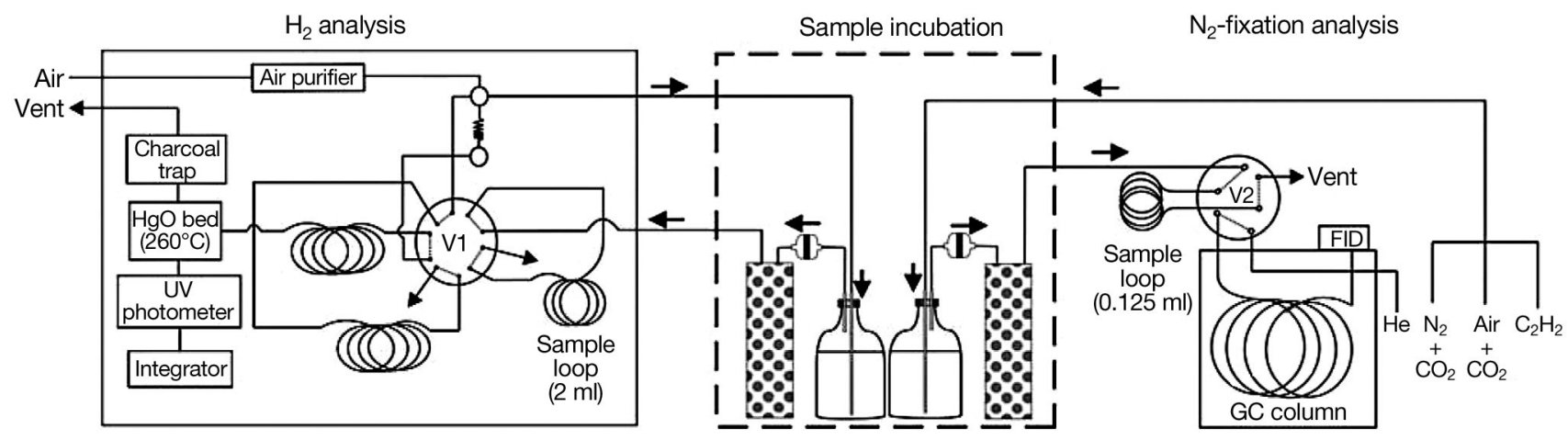

Fig. 1. Analytical design for $\mathrm{H}_{2}$ production and acetylene reduction assays. During the experimental period, cultures were kept in the incubator (dashed line) and purged under continual gas flow (indicated by the direction of the arrows). The exit lines incorporated hydrophobic filters and nafion driers to remove water vapor from the sample gas stream. The gas lines led either to a 10-port switching valve (V1) which injected $2 \mathrm{ml}$ of the sample stream for $\mathrm{H}_{2}$ analysis using a $\mathrm{HgO}$ bed (Peak Laboratories), or a 6-port switching valve (V2) which injected $0.125 \mathrm{ml}$ onto the gas chromatography (GC) column for ethylene analysis by gas chromatography-flame ionization detection (GC-FID) (Agilent Technologies). The diagram shows the valves in their 'purge' position 
instrument drift was negligible $(<0.1 \%$ difference in the calibration slope).

Nitrogenase activity. Nitrogenase activity was measured using an on-line monitoring $\mathrm{C}_{2} \mathrm{H}_{2}$ reduction assay similar to that described by Staal et al. (2001). The system was modified to keep the sample conditions identical to those used in the $\mathrm{H}_{2}$ analysis (Fig. 1). The main modification was to replace the stainless steel sample cell with a $240 \mathrm{ml}$ crimp-sealed borosilicate glass vial fitted with an inlet and outlet. One drawback of using a larger volume was that it increased the time required to purge the sample to $16 \mathrm{~min}$ at a gas flow rate of $17 \mathrm{ml} \mathrm{min}^{-1}$ (compared to 4 min using the sample cell described by Staal et al. 2001). The purge gas ran continually and was composed of $70 \% \mathrm{~N}_{2}$ (containing $300 \mathrm{ppm} \mathrm{CO}_{2}$ ), $20 \% \mathrm{O}_{2}$ (containing $300 \mathrm{ppm} \mathrm{CO}_{2}$ ), and $10 \% \mathrm{C}_{2} \mathrm{H}_{2}$. A consistent and reproducible signal was recorded for $\mathrm{C}_{2} \mathrm{H}_{4}$ production at a concentration of $10 \% \mathrm{C}_{2} \mathrm{H}_{2}$ without the risk of starving the cells of nitrogen at a higher $\mathrm{C}_{2} \mathrm{H}_{2}$ concentration. $\mathrm{A}_{2} \mathrm{H}_{4}$ background peak was quantified on blank samples and subsequently subtracted from the measurements. After exiting the sample culture, the gas flow was dried by passing through a nafion drier to a 6-port switching valve that injected $125 \mu \mathrm{l}$ into an Agilent Technologies gas chromatograph (GC) (Model 6850 Series II) fitted with a fused silica Porapak U capillary column $(25 \mathrm{~m} \times 0.53 \mathrm{~mm}$; Chrompack). The conditions of the GC were as follows: injector, detector, and oven temperatures were 90, 155, and $45^{\circ} \mathrm{C}$, respectively. The carrier gas was helium at a flow rate of $3.6 \mathrm{ml} \mathrm{min} \mathrm{m}^{-1}$, and the $\mathrm{H}_{2}$ and air to the detector were 35 and $400 \mathrm{ml} \mathrm{min}^{-1}$, respectively. The retention time for $\mathrm{C}_{2} \mathrm{H}_{4}$ was $1.94 \mathrm{~min}$ and 1 full run took $4 \mathrm{~min}$. The detection limit for this particular set-up was approximately $0.8 \mathrm{nmol} \mathrm{C}_{2} \mathrm{H}_{4} \mathrm{l}^{-1} \mathrm{~h}^{-1}$, which equates to a $\mathrm{C}_{2} \mathrm{H}_{4}$ production rate of $0.03 \mathrm{nmol} \mathrm{C}_{2} \mathrm{H}_{4}$ $(\mu \mathrm{g} \text { chl } a)^{-1} \mathrm{~h}^{-1}$. The software used was Chemstation version A.09.03 (Agilent Technologies). $\mathrm{C}_{2} \mathrm{H}_{4}$ calibrations were performed using dilutions of $2 \mathrm{C}_{2} \mathrm{H}_{4}$ standards (100 ppm and 9.9 ppm; Scotty Gases). Nitrogenase activity is reported as $\mathrm{C}_{2} \mathrm{H}_{4}$ production, except when the ratio of $\mathrm{N}_{2}$ fixation to $\mathrm{H}_{2}$ production is compared with the theoretical stoichiometry in Eq. (1). To convert $\mathrm{C}_{2} \mathrm{H}_{4}$ production rates to $\mathrm{N}_{2}$ fixation, a ratio of $4 \mathrm{~mol}$ of $\mathrm{C}_{2} \mathrm{H}_{4}$ produced per mol $\mathrm{N}_{2}$ reduced was used (Capone 1993, Mulholland et al. 2004).

Experimental manipulation. To test whether the $\mathrm{H}_{2}$ evolved was due to nitrogenase activity, ammonium $\left(\mathrm{NH}_{4}^{+}\right)$was added as a source of fixed nitrogen to all cultures (final concentration of $20 \mu \mathrm{mol} \mathrm{l}^{-1}$ ). $\mathrm{NH}_{4}{ }^{+}$has previously been used to inhibit nitrogenase synthesis in both natural populations (Capone et al. 1990) and cultures of Trichodesmium erythraeum IMS101 (Chen et al. 1996).

\section{RESULTS}

The production of $\mathrm{H}_{2}$ was detected in all cultures of Trichodesmium erythraeum IMS101, Cyanothece sp. ATCC 51142, and both strains of Crocosphaera watsonii. $\mathrm{H}_{2}$ production was correlated with rates of ethylene production in all instances and was suppressed in all cultures by the addition of $\mathrm{NH}_{4}{ }^{+}$as a fixed source of nitrogen, indicating that nitrogenase was the likely source of the $\mathrm{H}_{2}$.

\section{Trichodesmium erythraeum IMS101}

Nitrogenase activity followed a diel cycle, with activity increasing rapidly after the beginning of the light period (Fig. 2). $\mathrm{C}_{2} \mathrm{H}_{4}$ production reached a maximum of $32 \mathrm{nmol} \mathrm{C}_{2} \mathrm{H}_{4}$ ( $\mathrm{gg}$ chl a $)^{-1} \mathrm{~h}^{-1}$ in the cultures. $\mathrm{H}_{2}$ production in Trichodesmium erythraeum IMS101 cultures also occurred during the light period (08:00 to 20:00 h). Net production of $\mathrm{H}_{2}$ began at the onset of the light period and increased rapidly for the first $3 \mathrm{~h}$. The highest rates of $\mathrm{H}_{2}$ production reached $3 \mathrm{nmol} \mathrm{H}_{2}$ ( $\mu \mathrm{g}$ chl a) ${ }^{-1} \mathrm{~h}^{-1}$. The peak of $\mathrm{H}_{2}$ production in $T$. erythraeum IMS101 was broad compared to the unicellular cultures and extended for 3 to $4 \mathrm{~h}$ before concentrations decreased. On 1 sampling occasion $\mathrm{H}_{2}$ was still being produced at the end of the light period $(0.1$ to $0.3 \mathrm{nmol} \mathrm{H}_{2}$ [ $\left.\mu \mathrm{g} \mathrm{chl} \mathrm{a}\right]^{-1} \mathrm{~h}^{-1}$ ) and the onset of the dark period stimulated an immediate decrease in $\mathrm{H}_{2}$ production (Fig. 2A).

\section{Cyanothece sp. ATCC 51142}

An increase in nitrogenase activity by Cyanothece sp. ATCC 51142 was detected approximately $1 \mathrm{~h}$ after the onset of the dark period and increased steadily to reach a maximum rate of $24 \mathrm{nmol} \mathrm{C}_{2} \mathrm{H}_{4}$ ( $\mu \mathrm{g} \mathrm{chl} \mathrm{a})^{-1} \mathrm{~h}^{-1}$ in the middle of the night (Fig. 3). Maximum rates of nitrogenase activity were sustained for 1 to $2 \mathrm{~h}$ before decreasing again and were typically back to zero before the end of the dark period. Net $\mathrm{H}_{2}$ production also increased during the night, although it was delayed by $4 \mathrm{~h}$ after the onset of the dark period, approximately $2 \mathrm{~h}$ after the onset of $\mathrm{C}_{2} \mathrm{H}_{4}$ production. Concentrations of $\mathrm{H}_{2}$ increased for $2 \mathrm{~h}$, reaching a maximum production rate of 0.3 to $0.5 \mathrm{nmol} \mathrm{H}_{2}$ ( $\mu \mathrm{g}$ chl a $)^{-1} \mathrm{~h}^{-1} \cdot \mathrm{H}_{2}$ production subsequently declined and was not detected by the end of the dark period. In comparison to the $2 \mathrm{~h}$ time difference between the increase of $\mathrm{H}_{2}$ and $\mathrm{C}_{2} \mathrm{H}_{4}$ production in the Cyanothece sp. ATCC 51142 cultures, both $\mathrm{H}_{2}$ and $\mathrm{C}_{2} \mathrm{H}_{4}$ production decreased at approximately similar times. 


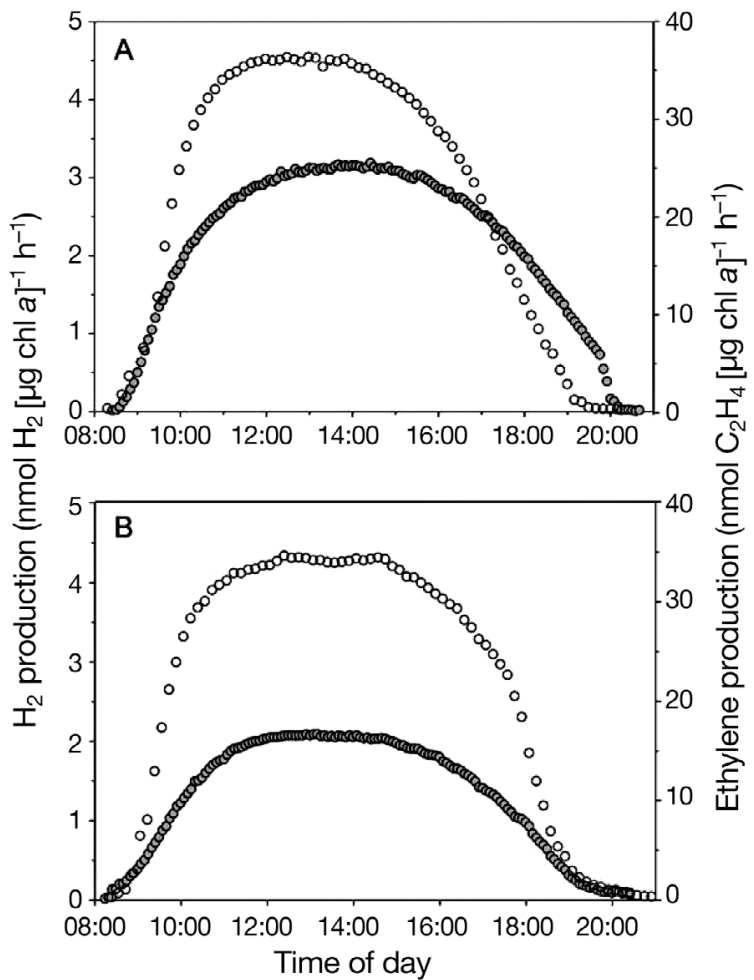

Fig. 2. Trichodesmium erythraeum strain IMS101. Chlorophyll-normalized rates of ethylene production $(\mathrm{O})$ and net $\mathrm{H}_{2}$ production (O). Measurements were repeated on (A) 26 May and (B) 2 June 2009. The light period in both experiments extended from 08:00 to 20:00 h

\section{Crocosphaera watsonii}

Nitrogenase activity occurred during the dark period for both strains of Crocosphaera watsonii. The maximum rates of $\mathrm{C}_{2} \mathrm{H}_{4}$ production were 24 and $16 \mathrm{nmol}$

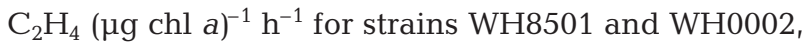
respectively (Figs. 4 \& 5). Maximum $\mathrm{H}_{2}$ production rates were 0.028 and $0.018 \mathrm{nmol} \mathrm{H}_{2}(\mu \mathrm{g} \mathrm{chl} \mathrm{a})^{-1} \mathrm{~h}^{-1}$ for strains WH8501 and WH0002, respectively. These values represent the lowest concentrations of $\mathrm{H}_{2}$ measured in the Cyanobacteria cultures during the present study. Net production rates of $\mathrm{H}_{2}$ were an order of magnitude lower than with Cyanothece sp. ATCC 51142 and were close to the detection limit for the analytical system.

During the experimental incubations, both Crocosphaera watsonii strains WH8501 and WH0002 formed a mat on the bottom of the culture glass vial, even in the presence of a continual gas flow. This was minimized by gentle swirling of the flask throughout the sampling period. This is likely to have contributed to the higher variability of the measurements observed in the C. watsonii cultures (e.g. Fig. 4A), which likely also reflect the low $\mathrm{H}_{2}$ concentration.

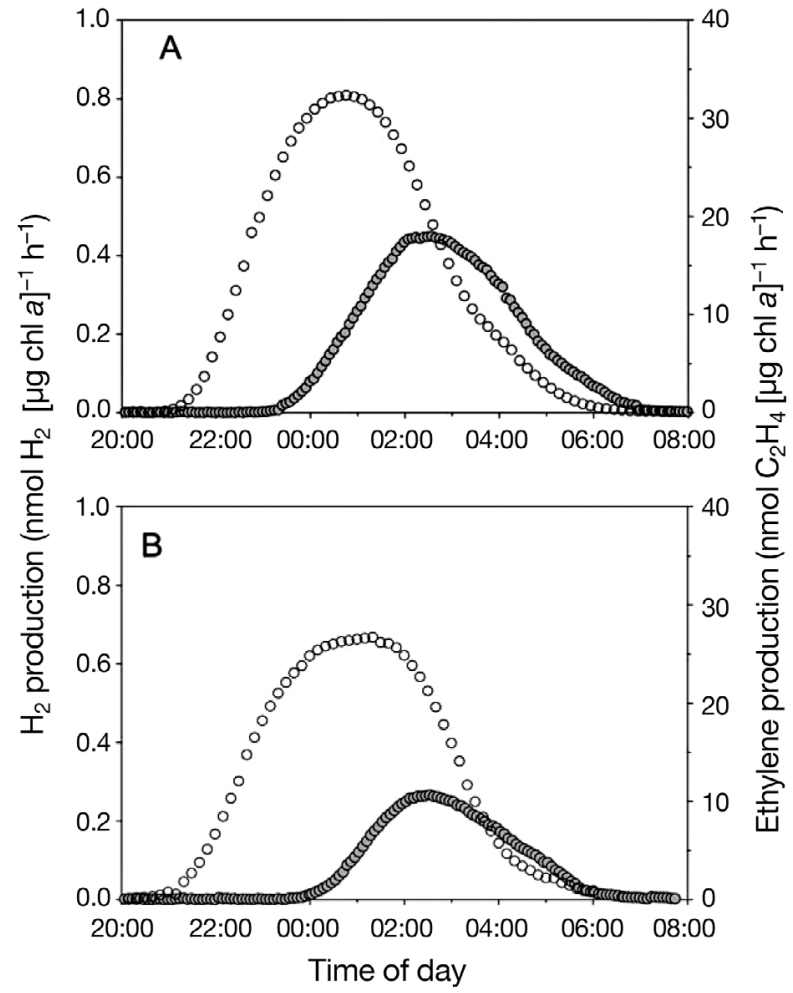

Fig. 3. Cyanothece sp. strain ATCC 51142. Chlorophyllnormalized rates of ethylene production (O) and net $\mathrm{H}_{2}$ production (O). Measurements were repeated on (A) 28 May and (B) 4 June 2009. The dark period in both experiments extended from 20:00 to 08:00 $\mathrm{h}$

\section{$\mathbf{N}_{2}$ fixation}

The stoichiometry of $\mathrm{H}_{2}$ production as part of the $\mathrm{N}_{2}$ fixation process can be considered by converting $\mathrm{C}_{2} \mathrm{H}_{4}$ production to $\mathrm{N}_{2}$ fixation. Trichodesmium erythraeum IMS101 was not only the dominant producer of $\mathrm{H}_{2}$, but also produced the highest concentration of $\mathrm{H}_{2}$ relative to $\mathrm{N}_{2}$ fixation. The $\mathrm{H}_{2}$ production to $\mathrm{N}_{2}$ fixation ratios for $T$. erythraeum IMS101 ranged from 0.25 to 0.34 , compared to 0.04 to 0.055 for Cyanothece sp. ATCC 51142. The 2 strains of Crocosphaera watsonii produced the least amount of $\mathrm{H}_{2}$ relative to nitrogenase activity, and the average $\mathrm{H}_{2}$ production to $\mathrm{N}_{2}$ fixation ratios were 0.004 and 0.003 for strains WH8501 and WH0002, respectively.

\section{Addition of $\mathrm{NH}_{4}{ }^{+}$}

The addition of $\mathrm{NH}_{4}{ }^{+}$inhibited nitrogenase activity and $\mathrm{H}_{2}$ production in the cultures (Fig. 6A). It was added in the light or dark period prior to the active nitrogenase period for each organism. The rates of $\mathrm{C}_{2} \mathrm{H}_{4}$ production decreased by 80 to $90 \%$ on all occa- 


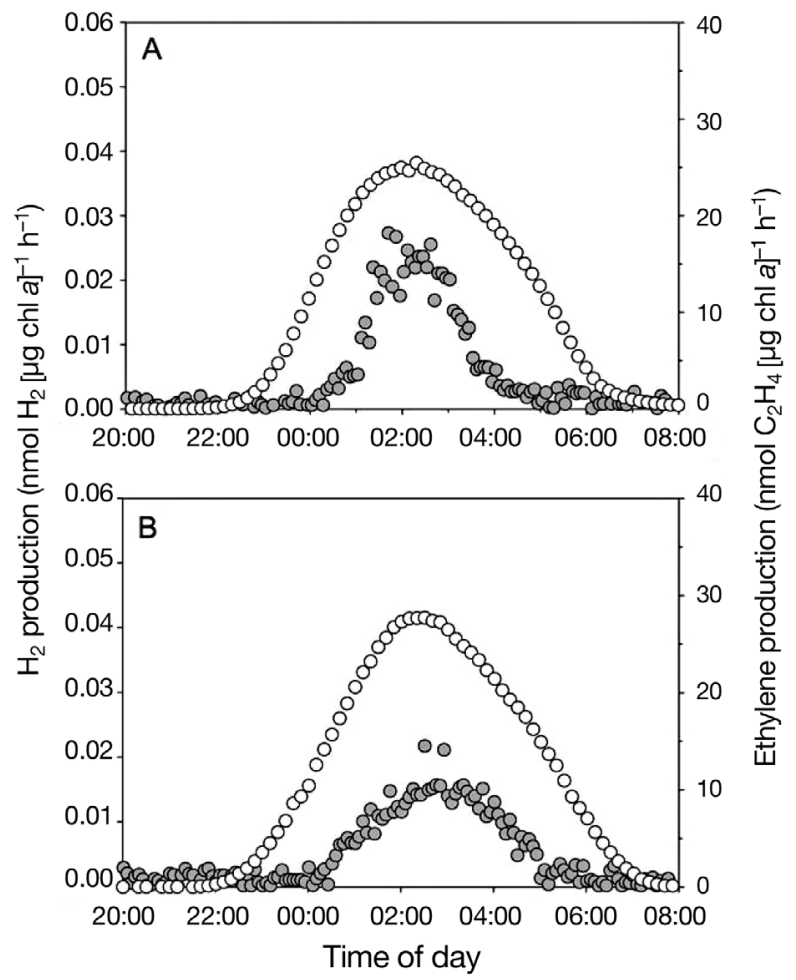

Fig. 4. Crocosphaera watsonii strain WH8501. Chlorophyllnormalized rates of ethylene production (O) and net $\mathrm{H}_{2}$ production (O). Measurements were repeated on (A) 5 June and (B) 20 June 2009. The dark period in both experiments extended from 20:00 to 08:00 $\mathrm{h}$

sions. Fig. 6A shows the effect of adding $\mathrm{NH}_{4}{ }^{+}$during the middle of the light period to a culture of Trichodesmium erythraeum IMS101 that was actively fixing $\left.\mathrm{N}_{2}\left(20 \mathrm{nmol} \mathrm{C}_{2} \mathrm{H}_{4} \text { [ } \mathrm{\mu g} \mathrm{chl} \mathrm{a}\right]^{-1} \mathrm{~h}^{-1}\right)$ and producing $\mathrm{H}_{2}$ $\left(\sim 1 \mathrm{nmol} \mathrm{H}_{2}[\mu \mathrm{g} \mathrm{chl} \mathrm{a}]^{-1} \mathrm{~h}^{-1}\right)$. There was an immediate decrease in the rate of $\mathrm{C}_{2} \mathrm{H}_{4}$ and $\mathrm{H}_{2}$ production, and concentrations of $\mathrm{H}_{2}$ subsequently decreased steadily over the next 2 to $3 \mathrm{~h}$. Similarly, $\mathrm{C}_{2} \mathrm{H}_{4}$ and $\mathrm{H}_{2}$ production were also inhibited in T. erythraeum IMS101 by removing the light source (Fig. 6B). In comparison to adding $\mathrm{NH}_{4}{ }^{+}, \mathrm{C}_{2} \mathrm{H}_{4}$ production decreased more rapidly to reach $10 \%$ of pre-treatment values within $40 \mathrm{~min}$ when the lights were turned off. $\mathrm{H}_{2}$ production also decreased, yet there was little apparent difference between the 2 treatments.

\section{DISCUSSION}

Diazotrophic Cyanobacteria are widespread in the world's oceans where they are estimated to provide approximately $100 \mathrm{Tg} \mathrm{yr}^{-1}$ of fixed $\mathrm{N}$ to the marine ecosystem (Karl et al. 2002). As a by-product of the $\mathrm{N}_{2}$ fixation process, the diazotrophic Cyanobacteria also produce $\mathrm{H}_{2}$ in the surface waters of the world's oceans.

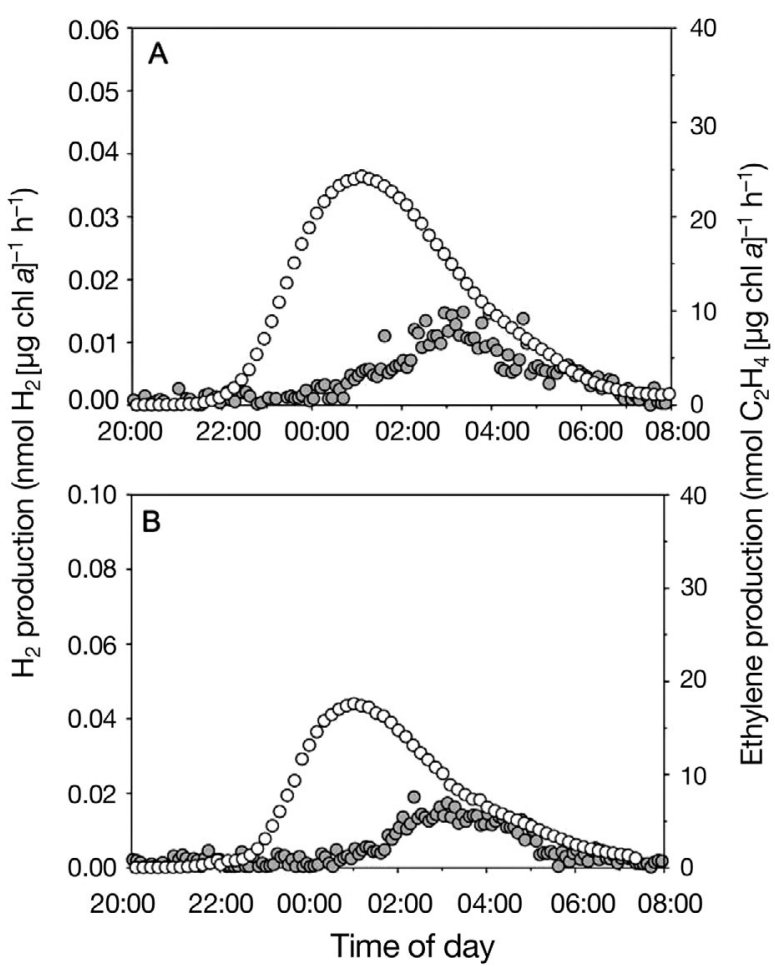

Fig. 5. Crocosphaera watsonii strain WH0002. Chlorophyllnormalized rates of ethylene production (O) and net $\mathrm{H}_{2}$ production (O). Measurements were repeated on (A) 6 June and (B) 14 June 2009. The dark period in both experiments extended from 20:00 to $08: 00 \mathrm{~h}$

The present study measured $\mathrm{N}_{2}$ fixation and $\mathrm{H}_{2}$ production in cultures of several $\mathrm{N}_{2}$ fixing Cyanobacteria (Trichodesmium erythraeum IMS101, Cyanothece sp. ATCC 51142, and Crocosphaera watsonii WH8501 and WH0002) to determine their potential contribution to the dissolved $\mathrm{H}_{2}$ present in the upper ocean.

All of the cultures of Cyanobacteria exhibited diel patterns of nitrogenase activity as previously reported, with fixation during the light period for Trichodesmium erythraeum IMS101 (Chen et al. 1996, Berman-Frank et al. 2001) and night-time nitrogenase activity for Cyanothece sp. (Sherman et al. 1998) and Crocosphaera watsonii (Tuit et al. 2004). Outside of these time periods, no nitrogenase activity was detected using the continual on-line acetylene reduction assay. $\mathrm{C}_{2} \mathrm{H}_{4}$ production rates in T. erythraeum IMS101 cultures reached a maximum of $32 \mathrm{nmol} \mathrm{C}_{2} \mathrm{H}_{4}(\mu \mathrm{g}$ chl a $)^{-1} \mathrm{~h}^{-1}$, which is comparable to previous measurements (Chen et al. 1996). Compared to the unicellular Cyanobacteria, nitrogenase activity by $T$. erythraeum IMS101 cultures extended over a longer time period. The rates of $\mathrm{C}_{2} \mathrm{H}_{4}$ production in Crocosphaera watsonii WH8501 and WH0002 (24 and $16 \mathrm{nmol} \mathrm{C}_{2} \mathrm{H}_{4}$ $[\mu \mathrm{g} \mathrm{chl} \mathrm{a}]^{-1} \mathrm{~h}^{-1}$, respectively) were higher than those recently reported for Crocosphaera watsonii WH8501 


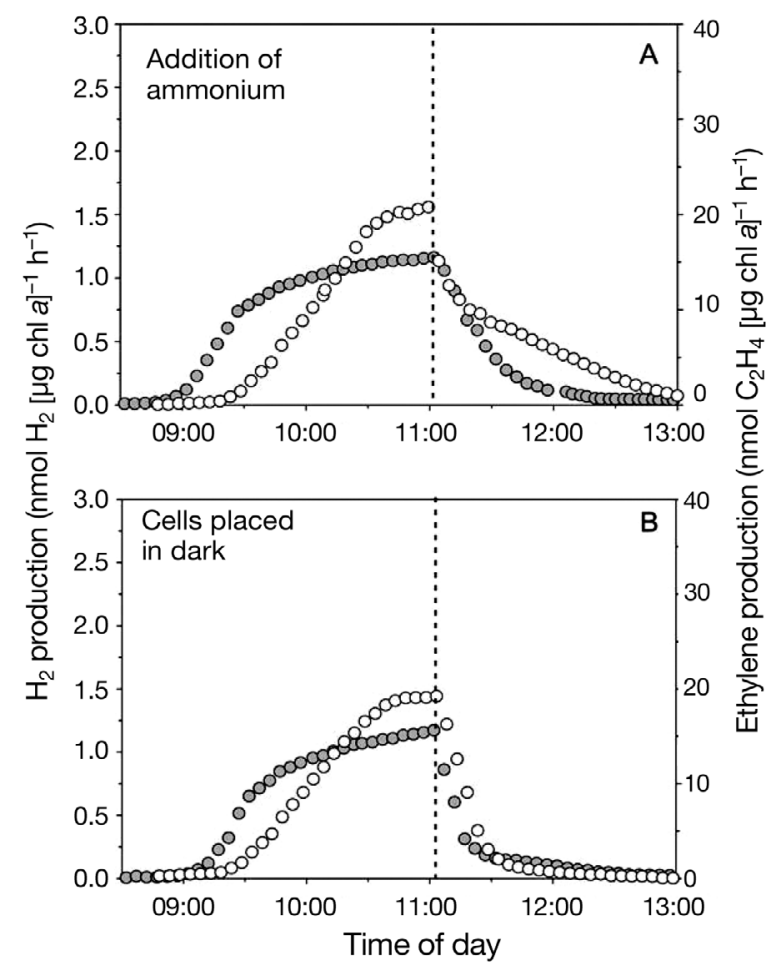

Fig. 6. Trichodesmium erythraeum strain IMS101. Effect of (A) ammonium and (B) darkness on ethylene production (O) and net $\mathrm{H}_{2}$ production (O). The dashed line represents when (A) ammonium was added (final concentration: $20 \mu \mathrm{mol} \mathrm{l}^{-1}$ ) or (B) the light source was removed

by Webb et al. (2009). One possible reason for the variation is the difference in the acetylene-reduction assay protocols. The on-line GC method used in the present study measured the flux of ethylene, compared to discrete batch incubations that can be incubated for over an hour. Comparisons between the discrete and continuous measurements have been documented for Nodularia spumigena (Staal et al. 2001), but should be carried out for other diazotrophic organisms, which may respond differently to the experimental conditions.

The highest rates of $\mathrm{H}_{2}$ production were measured in cultures of Trichodesmium erythraeum IMS101, with production reaching $3 \mathrm{nmol} \mathrm{H}(\mu \mathrm{g} \mathrm{chl} \mathrm{a})^{-1} \mathrm{~h}^{-1}$. These rates exceed those reported by Punshon \& Moore (2008) for the same strain of $T$. erythraeum (0.061 to $0.71 \mathrm{nmol} \mathrm{H}_{2}[\mu \mathrm{g} \mathrm{chl} \mathrm{a}]^{-1} \mathrm{~h}^{-1}$ ), which most likely reflects the higher $\mathrm{N}_{2}$ fixation rates measured in the present study (10 $\mathrm{nmol} \mathrm{N}_{2}[\mu \mathrm{g} \mathrm{chl} \mathrm{a}]^{-1} \mathrm{~h}^{-1}$ ) compared to the cultures of Punshon \& Moore (2008) (0.59 to $4.71 \mathrm{nmol}$ $\mathrm{N}_{2}[\mu \mathrm{g} \mathrm{chl} \mathrm{a}]^{-1} \mathrm{~h}^{-1}$ ). The rate of $\mathrm{H}_{2}$ production by T. erythraeum IMS101 is comparable to previously reported rates of 7.5 to $20 \mathrm{nmol} \mathrm{H}_{2}(\mu \mathrm{g} \mathrm{chl} \mathrm{a})^{-1} \mathrm{~h}^{-1}$ reported for other filamentous Cyanobacteria such as Anabaena sp. and Nostoc sp. (Bothe et al. 1980). In comparison to the filamentous Cyanobacteria, the rates of $\mathrm{H}_{2}$ production measured in the unicellular Cyanobacteria were lower $\left(0.3,0.04\right.$, and $0.03 \mathrm{nmol} \mathrm{H}_{2}[\mu \mathrm{g} \mathrm{chl} \mathrm{a}]^{-1} \mathrm{~h}^{-1}$ for Cyanothece sp. ATCC 51142 and Crocosphaera watsonii WH8501 and WH0002, respectively). These rates are lower than night-time $\mathrm{H}_{2}$ production rates of 1.7 and $0.2 \mathrm{nmol} \mathrm{H}_{2}(\mu \mathrm{g} \mathrm{chl} a)^{-1} \mathrm{~h}^{-1}$ reported for the unicellular, $\mathrm{N}_{2}$ fixing Cyanothece sp. strain 7822 and Synechococcus sp. strain 7425, respectively (Van der Oost et al. 1987). However, in the study by Van der Oost et al. (1987), the rates of $\mathrm{H}_{2}$ production exceed the stoichiometric rate of $\mathrm{N}_{2}$ fixation, indicating another source of $\mathrm{H}_{2}$ in addition to nitrogenase. In contrast, the $\mathrm{H}_{2}$ production rates of the unicellular Cyanobacteria analyzed in the present study compare favorably with those reported for other unicellular, albeit non- $\mathrm{N}_{2}$ fixing, Cyanobacteria, which range from 0.02 to $0.48 \mathrm{nmol} \mathrm{H}_{2}(\mu \mathrm{g} \mathrm{chl} \mathrm{a})^{-1} \mathrm{~h}^{-1}$ for Synechococcus sp. and $0.06 \mathrm{H}_{2}(\mu \mathrm{g} \mathrm{chl} a)^{-1} \mathrm{~h}^{-1}$ for Synechocystis sp. strain PCC 6308 (Howarth \& Codd 1985).

The $\mathrm{C}_{2} \mathrm{H}_{4}$ production and $\mathrm{H}_{2}$ production results of the present study complement the findings of previous work, that also showed that the filamentous Cyanobacteria fix more $\mathrm{N}_{2}$ per cell volume (Mahaffey et al. 2005) and produce more $\mathrm{H}_{2}$ (Schütz et al. 2004) than their unicellular counterparts. Ratios of $\mathrm{H}_{2}$ production to $\mathrm{N}_{2}$ fixation can be compared with the gross theoretical stoichiometric model of 1:1 (Eq. 1) by converting $\mathrm{C}_{2} \mathrm{H}_{4}$ production to $\mathrm{N}_{2}$ fixation using a ratio of $4 \mathrm{~mol} \mathrm{C}_{2} \mathrm{H}_{4}$ produced per mol $\mathrm{N}_{2}$ reduced (Jensen \& Cox 1983, Capone 1993, Mulholland et al. 2004, Tuit et al. 2004). Ratios of $\mathrm{H}_{2}$ production to $\mathrm{N}_{2}$ fixation for Trichodesmium erythraeum IMS101, Cyanothece sp. ATCC 51142, and Crocosphaera watsonii WH8501 and WH0002 were $0.28,0.05,0.004$, and 0.003 , respectively. The deficit in $\mathrm{H}_{2}$ values from the 1:1 ratio is most likely due to $\mathrm{H}_{2}$ measurements not accounting for the subsequent re-incorporation of $\mathrm{H}_{2}$ by uptake hydrogenase (Bothe et al. 1980). Measurements of gross $\mathrm{H}_{2}$ production were not undertaken during the present study, but are an integral component of future work to resolve the cycling of $\mathrm{H}_{2}$ by diazotrophs. Possible methods to estimate gross $\mathrm{H}_{2}$ production rates include ${ }^{3} \mathrm{H}_{2}$-exchange assays (e.g. Paerl 1983), the inhibition of uptake hydrogenase by carbon monoxide (Smith et al. 1976), or genetic manipulation of the hydrogenase gene (e.g. Lindberg et al. 2002, Masukawa et al. 2002). The $\mathrm{H}_{2}: \mathrm{N}_{2}$ ratios will also be affected by the conversion factor selected for converting $\mathrm{C}_{2} \mathrm{H}_{2}$ reduction rates to $\mathrm{N}_{2}$ fixation rates, as variation in this ratio, either between species or at different stages of growth, would influence the calculated $\mathrm{H}_{2}$ yield (Punshon \& Moore 2008). Another potential factor affecting the $\mathrm{H}_{2}: \mathrm{N}_{2}$ ratio is the consumption of the $\mathrm{H}_{2}$ by chemoheterotrophic microorganisms. Although sterile labo- 
ratory techniques were used at all times, the cultures used in the present study were not axenic.

The ability of Trichodesmium erythraeum, Cyanothece sp., and Crocosphaera watsonii to re-incorporate the $\mathrm{H}_{2}$ produced during $\mathrm{N}_{2}$ fixation has important implications for cellular and ecological bioenergetics. The production of $\mathrm{H}_{2}$ during $\mathrm{N}_{2}$ fixation has previously been described as energetically wasteful (Prince \& Kheshgi 2005) as the $\mathrm{H}_{2}$ component of $\mathrm{N}_{2}$ fixation requires 2 electrons, compared to the 6 electrons required to reduce $\mathrm{N}_{2}$ to $\mathrm{NH}_{3}$ and at least 2 molecules of ATP per electron are needed (Eady 1996). One strategy for a diazotroph to reduce this energy loss is to reincorporate the $\mathrm{H}_{2}$ released via hydrogenase enzymes (Stephenson \& Stickland 1931). Uptake hydrogenases, which re-assimilate the $\mathrm{H}_{2}$ produced by nitrogenase, have been found in all $\mathrm{N}_{2}$ fixing Cyanobacteria examined, including Trichodesmium spp. (Saino \& Hattori 1982), Cyanothece sp. (Stöckel et al. 2008), and Crocosphaera sp. (Tamagnini et al. 2004).

The re-incorporation of $\mathrm{H}_{2}$ has numerous potential benefits for Cyanobacteria and the functioning of nitrogenase. The uptake hydrogenase could provide electrons for the electron transport chain, via a Knallgas reaction, resulting in phosphorylation of ADP to ATP and the simultaneous consumption of oxygen (Bothe et al. 1974, Robson \& Postgate 1980). Alternatively, hydrogenase could provide electrons to photosystem I, which would generate reductant, rather than ATP, from the $\mathrm{H}_{2}$ produced by nitrogenase (Dixon 1972). In the present study, the lower net production rates by the unicellular Cyanobacteria may indicate that they are more efficient at recycling the $\mathrm{H}_{2}$ produced by nitrogenase, as previously suggested by Schütz et al. (2004). The recycling of $\mathrm{H}_{2}$ could also explain the offset observed during the diel cycle between $\mathrm{H}_{2}$ production and $\mathrm{N}_{2}$ fixation (e.g. Fig. 3). The lag time between the $\mathrm{N}_{2}$ fixation and the $\mathrm{H}_{2}$ production rate may reflect a higher rate of $\mathrm{H}_{2}$ re-assimilation during the period of maximum $\mathrm{N}_{2}$ fixation.

In addition to the importance of $\mathrm{H}_{2}$ cycling at the cellular level, the results of the present work allow the diversity and activity of $\mathrm{N}_{2}$ fixing Cyanobacteria in the marine environment to be linked with the concentration of dissolved $\mathrm{H}_{2}$. A recent oceanographic cruise across the equatorial Pacific measured dissolved $\mathrm{H}_{2}$ concentrations and also $\mathrm{N}_{2}$ fixation using size-fractionated ${ }^{15} \mathrm{~N}_{2}$ uptake (Moore et al. 2009). The $<10 \mu \mathrm{m}$ size class (assumed to be unicellular Cyanobacteria) contributed 36 to $100 \%$ to the whole community $\mathrm{N}_{2}$ fixation rates, which ranged from 0.18 to $9.0 \mu \mathrm{mol} \mathrm{N}_{2}$ $\mathrm{m}^{-3} \mathrm{~d}^{-1}$. Estimated rates of net $\mathrm{H}_{2}$ production across the equatorial Pacific ranged from 0 to $0.059 \mu \mathrm{mol}$ $\mathrm{H}_{2} \mathrm{~m}^{-3} \mathrm{~d}^{-1}$ with an average of $0.17 \mu \mathrm{mol} \mathrm{H}_{2} \mathrm{~m}^{-3} \mathrm{~d}^{-1}$ (Moore et al. 2009). Applying the $\mathrm{H}_{2}: \mathrm{N}_{2}$ ratios from the present study (0.3 and 0.003 for Trichodesmium erythraeum IMS101 and Crocosphaera watsonii, respectively) to average values of $\mathrm{H}_{2}$ production and $\mathrm{N}_{2}$ fixation for the whole cruise indicate $\mathrm{H}_{2}$ production rates for T. erythraeum and C. watsonii of 0.129 and $0.003 \mu \mathrm{mol} \mathrm{H}_{2} \mathrm{~m}^{-3} \mathrm{~d}^{-1}$, respectively. These estimates support previous suggestions that Trichodesmium spp. makes a substantial contribution to the pool of dissolved $\mathrm{H}_{2}$ in the upper ocean (Scranton 1983, Punshon \& Moore 2008). However, careful corroboration of the laboratory-based measurements with in situ net $\mathrm{H}_{2}$ production rates in the natural environment is required. This is particularly pertinent because measurements of $\mathrm{H}_{2}$ production by field-collected colonies of $T$. thiebautii revealed $\mathrm{H}_{2}$ production to $\mathrm{N}_{2}$ fixation ratios ranging from 0.01 to 0.06 (Scranton et al. 1987), an order of magnitude lower than cultures of $T$. erythraeum IMS101 analyzed in the present study. One possible explanation is the difference in light intensity between cultures and field-collected organisms. However, an increased light intensity increases $\mathrm{N}_{2}$ fixation in Trichodesmium spp. (Berman-Frank et al. 2001) and would therefore be predicted to increase, rather than decrease, $\mathrm{H}_{2}$ production. Efforts are currently being made to improve the experimental design for further physiological experiments to measure $\mathrm{N}_{2}$ fixation and $\mathrm{H}_{2}$ production.

It should be noted that in addition to a nitrogenase source of $\mathrm{H}_{2}$, the fermentation of organic material by Cyanobacteria can also produce $\mathrm{H}_{2}$ (Schütz et al. 2004). In the present study, the addition of $\mathrm{NH}_{4}{ }^{+}$to the cultures inhibited both $\mathrm{N}_{2}$ fixation and $\mathrm{H}_{2}$ production, indicating that nitrogenase was the source of the $\mathrm{H}_{2}$ measured. This is to be expected, as the cultures were constantly aerated, which constrains the anaerobic conditions required for $\mathrm{H}_{2}$ production via fermentation by Cyanobacteria (Rupprecht et al. 2006), and furthermore the medium was devoid of fermentable organics. In the oxygenated upper ocean, fermentation metabolism by Cyanobacteria is likely to be minor in comparison to aerobic respiration (Stal \& Moezelaar 1997) and $\mathrm{H}_{2}$ is more likely to evolve from $\mathrm{N}_{2}$ fixation.

\section{CONCLUSIONS}

The present work showed the production of $\mathrm{H}_{2}$ by Trichodesmium erythraeum IMS101, Cyanothece sp. ATCC 51142, and Crocosphaera watsonii in conjunction with $\mathrm{N}_{2}$ fixation. As demonstrated by previous work on filamentous and colonial Cyanobacteria, cultures of T. erythraeum IMS101 produced comparatively high concentrations of $\mathrm{H}_{2}$ relative to the rates of $\mathrm{N}_{2}$ fixation. In contrast, the unicellular diazotrophs pro- 
duced less $\mathrm{H}_{2}$, which is considered to reflect a higher efficiency of $\mathrm{H}_{2}$ scavenging following its production by nitrogenase. An efficient recycling of $\mathrm{H}_{2}$ would alleviate some of the rigorous metabolic requirements associated with nitrogenase activity by providing ATP, a supply of reductant and mitigating the effects of oxygen. Therefore, intracellular cycling of $\mathrm{H}_{2}$ may prove to be essential for an efficient functioning of these diazotrophs, which have recently been identified as key players in the fixation of $\mathrm{N}_{2}$ in the open ocean. Despite the important role of unicellular diazotrophs in global $\mathrm{N}_{2}$ fixation, it appears that Trichodesmium spp. is producing much of the dissolved $\mathrm{H}_{2}$ in the upper oceans. This suggests that changes in the distribution and physiology of Trichodesmium spp. could also indirectly affect the levels of dissolved $\mathrm{H}_{2}$ in the ocean. This would not only have repercussions for the ocean as a source of $\mathrm{H}_{2}$ to the atmosphere, but could also affect the availability of $\mathrm{H}_{2}$ to marine microorganisms as a potential source of energy and reducing power. The role of $\mathrm{H}_{2}$ in the energy budget of the upper ocean is not well known and the present study is an important reminder of its availability.

Acknowledgements. We thank M. Hogan, R. Frank, and R. Kudela for laboratory assistance. S. Bench and J. Waterbury provided the cultures. We also thank the anonymous reviewers for their comments and helpful suggestions. This research was supported by the Gordon and Betty Moore Foundation and the National Science Foundation (NSF) Center for Microbial Oceanography: Research and Education (C-MORE).

\section{LITERATURE CITED}

Asada Y, Miyake J (1999) Photobiological hydrogen production. J Biosci Bioeng 88:1-6

Berman-Frank I, Lundgren P, Chen YB, Küpper H, Kolber Z, Bergman B, Falkowski P (2001) Segregation of nitrogen fixation and oxygenic photosynthesis in the marine cyanobacterium Trichodesmium. Science 294:1534-1537

Bothe H, Falkenberg B, Nolteernsting U (1974) Properties and function of the pyruvate:ferredoxin oxidoreductase from the blue-green alga Anabaena cylindrica. Arch Microbiol 86:241-254

Bothe H, Neuer G, Kalbe I, Eisbrenner G (1980) Electron donors and hydrogenase in nitrogen-fixing microorganisms. In: Stewart WDP, Gallon JR (eds) Nitrogen fixation. Academic Press, London, p 83-112

Burns RC, Hardy RWF (1975) Nitrogen fixation in bacteria and higher plants. Springer Verlag, Heidelberg

Capone DG (1993) Determination of nitrogenase activity in aquatic samples using the acetylene reduction procedure. In: Kemp PF, Sherr BF, Sherr EB, Cole JJ (eds) Handbook of methods in aquatic microbial ecology. Lewis Publishers, Boca Raton, FL, p 621-631

Capone DG, O'Neil JM, Zehr JP, Carpenter EJ (1990) Basis for diel variation in nitrogenase activity in the marine planktonic cyanobacterium Trichodesmium thiebautii. Appl Environ Microbiol 56:3532-3536

Capone DG, Zehr JP, Paerl HW, Bergman B, Carpenter EJ
(1997) Trichodesmium, a globally significant marine cyanobacterium. Science 276:1221-1229

Chen YB, Zehr JP, Mellon M (1996) Growth and nitrogen fixation of the diazotrophic filamentous nonheterocystous cyanobacterium Trichodesmium sp. IMS101 in defined media: evidence for a circadian rhythm. J Phycol 32: 916-923

Conrad R (1988) Biogeochemistry and ecophysiology of atmospheric $\mathrm{CO}$ and $\mathrm{H}_{2}$. Adv Microb Ecol 10:231-283

Conrad R, Seiler W (1988) Methane and hydrogen in seawater (Atlantic Ocean). Deep-Sea Res A 35:1903-1917

Dixon ROD (1972) Hydrogenase in legume root nodule bacteroids: occurrence and properties. Arch Microbiol 85: 193-201

Eady RR (1996) Structure-function relationships of alternative nitrogenases. Chem Rev 96:3013-3030

Ehhalt D, Prather M (2001). Atmospheric chemistry and greenhouse gases. In: Houghton JT, et al. (eds) Climate change 2001: the scientific basis. Cambridge University Scientific Press, Cambridge, p 239-287

> Hauglustaine DA, Ehhalt DH (2002) A three-dimensional model of molecular hydrogen in the troposphere. J Geophys Res Atmos 107, 4330, doi:10.1029/2001JD001156

Herr FL, Scranton MI, Barger WR (1981) Dissolved hydrogen in the Norwegian Sea: mesoscale surface variability and deep water distribution. Deep-Sea Res A 28:1001-1016

Herr FL, Frank EC, Leone GM, Kennicutt MC (1984) Diurnal variability of dissolved molecular hydrogen in the tropical South Atlantic Ocean. Deep-Sea Res A 31:13-20

- Howard JB, Rees DC (2006) How many metals does it take to fix $\mathrm{N}_{2}$ ? A mechanistic overview of biological nitrogen fixation. Proc Natl Acad Sci USA 103:17088-17093

Howarth DC, Codd GA (1985) The uptake and production of molecular hydrogen by unicellular cyanobacteria. J Gen Microbiol 131:1561-1569

> Jensen BB, Cox R (1983) Direct measurements of steady-state kinetics of cyanobacterial $\mathrm{N}_{2}$ uptake by membrane-leak mass spectrometry and comparisons between nitrogen fixation and acetylene reduction. Appl Environ Microbiol 45:1331-1337

> Karl DM, Letelier R, Tupas L, Dore J, Hebel D (1997) The role of nitrogen fixation in the subtropical North Pacific Ocean. Nature 388:533-538

Karl D, Michaels A, Bergman B, Capone D and others (2002) Dinitrogen fixation in the world's oceans. Biogeochemistry 57-58:47-98

> Lindberg P, Schütz K, Happe T, Lindblad P (2002) A hydrogen-producing, hydrogenase-free mutant strain of Nostoc punctiforme ATCC 29133. Int J Hydrogen Energy 27: 1291-1296

Lowe DJ, Thorneley RNF (1984) The mechanism of Klebsiella pneumoniae nitrogenase action. Biochem J 224:877-909

Mahaffey C, Michaels AF, Capone DG (2005) The conundrum of marine $\mathrm{N}_{2}$ fixation. Am J Sci 305:546-595

Masukawa H, Mochimaru M, Sakurai H (2002) Disruption of the uptake hydrogenase gene, but not of the bidirectional hydrogenase gene, leads to enhanced photobiological hydrogen production by the nitrogen-fixing cyanobacterium Anabaena sp. PCC 7120. Appl Microbiol Biotechnol 58:618-624

> Mitsui A, Suda S (1995) Alternative and cyclic appearance of $\mathrm{H}_{2}$ and $\mathrm{O}_{2}$ photoproduction activities under non-growing conditions in an aerobic nitrogen-fixing unicellular cyanobacterium Synechococcus sp. Curr Microbiol 30:1-6

Moore RM, Punshon S, Mahaffey C, Karl D (2009) The relationship between dissolved hydrogen and nitrogen fixation in ocean waters. Deep-Sea Res I 56:1449-1458 
Mulholland MR, Bronk DA, Capone DG (2004) Dinitrogen fixation and release of ammonium and dissolved organic nitrogen by Trichodesmium IMS101. Aquat Microb Ecol 37:85-94

Paerl HW (1983) Environmental regulation of $\mathrm{H}_{2}$ utilization $\left({ }^{3} \mathrm{H}_{2}\right.$ exchange) among natural and laboratory populations of $\mathrm{N}_{2}$ and non- $\mathrm{N}_{2}$-fixing phytoplankton. Mar Biol 9:79-97

Prince RC, Kheshgi HS (2005) The photobiological production of hydrogen: potential efficiency and effectiveness as a renewable fuel. Crit Rev Microbiol 31:19-31

Prufert-Bebout L, Paerl HW, Lassen C (1993) Growth, nitrogen fixation and spectral attenuation in cultivated Trichodesmium species. Appl Environ Microbiol 59: 1367-1375

Punshon S, Moore RM (2008) Aerobic hydrogen production and dinitrogen fixation in the marine cyanobacterium Trichodesmium erythraeum IMS101. Limnol Oceanogr 53: $2749-2753$

Punshon S, Moore RM, Xie H (2007) Net loss rates and distribution of molecular hydrogen $\left(\mathrm{H}_{2}\right)$ in mid-latitude coastal waters. Mar Chem 105:129-139

Reddy KJ, Haskell B, Sherman D, Sherman LA (1993) Unicellular, aerobic nitrogen-fixing cyanobacteria of the genus Cyanothece. J Bacteriol 175:1284-1292

Robson RL, Postgate JR (1980) Oxygen and hydrogen in biological nitrogen fixation. Annu Rev Microbiol 34:183-207

Rupprecht J, Hankamer B, Mussgnug JH, Ananyev G, Disumkes C, Kruse O (2006) Perspectives and advances of biological $\mathrm{H}_{2}$ production in microorganisms. Appl Microbiol Biotechnol 72:442-449

Saino T, Hattori A (1982) Aerobic nitrogen fixation by the marine non-heterocystous cyanobacterium Trichodesmium (Oscillatoria) spp.: its protective mechanism against oxygen. Mar Biol 70:251-254

Schmidt U (1974) Molecular hydrogen in the atmosphere. Tellus 1-2:78-90

Schütz K, Happe T, Troshina O, Lindblad P, Leitão E, Oliveira $\mathrm{P}$, Tamagnini P (2004) Cyanobacterial $\mathrm{H}_{2}$ production - a comparative analysis. Planta 218:350-359

Scranton MI (1983) The role of the cyanobacterium Oscillatoria (Trichodesmium) thiebautii in the marine hydrogen cycle. Mar Ecol Prog Ser 11:79-87

Scranton MI, Novelli PC, Michaels A, Horrigan SC, Carpenter EJ (1987) Hydrogen production and nitrogen fixation by Oscillatoria thiebautii during in situ incubations. Limnol Oceanogr 32:998-1006

Seiler W, Schmidt U (1974) Dissolved non-conservative gases in seawater. In: Goldberg ED (ed) The sea, Vol 5. John Wiley \& Sons, New York, p 219-243

Editorial responsibility: Douglas Capone, Los Angeles, California, USA
Setser PJ, Bullister JL, Frank EC, Guinasso NL Jr, Schink DR (1982) Relationships between reduced gases, nutrients and fluorescence in surface waters off Baja, California. Deep-Sea Res A 29:1203-1215

Sherman LA, Meunier P, Colon-Lopez MS (1998) Diurnal rhythms in metabolism: a day in the life of a unicellular diazotrophic cyanobacterium. Photosynth Res 58:25-42

Smith LA, Hill S, Yates MG (1976) Inhibition by acetylene of conventional hydrogenase in nitrogen-fixing bacteria. Nature 262:209-210

Staal M, te Lintel-Hekkert S, Harren F, Stal L (2001) Nitrogenase activity in cyanobacteria measured by acetylene reduction assay: a comparison between batch incubation and on-line monitoring. Environ Microbiol 3:343-351

Stal LJ, Moezelaar R (1997) Fermentation in cyanobacteria. FEMS Microbiol Rev 21:179-211

Stephenson M, Stickland LH (1931) Hydrogenase: a bacterial enzyme activating molecular hydrogen. I. The properties of the enzyme. J Biochem 25:205-214

> Stöckel J, Welsh EA, Liberton M, Kunnvakkam R, Aurora R, Pakrasi HB (2008) Global transcriptomic analysis of Cyanothece 51142 reveals robust diurnal oscillation of central metabolic processes. Proc Natl Acad Sci USA 105: 6156-6161

Strickland JDH, Parsons TR (1972) A practical handbook of seawater analysis. Fisheries Research Board of Canada, Ottawa, ON

Tamagnini P, Leitão E, Oxelfelt F (2004) Uptake hydrogenase in cyanobacteria: novel input from non-heterocystous strains. Biochem Soc Trans 33:67-69

Tuit C, Waterbury J, Ravizza G (2004) Diel variation of molybdenum and iron in marine diazotrophic cyanobacteria. Limnol Oceanogr 49:978-990

Van der Oost J, Kanneworff WA, Krab K, Kraayenhof R (1987) Hydrogen metabolism of three unicellular nitrogen-fixing cyanobacteria. FEMS Microbiol Lett 48:41-45

Waterbury JB, Rippka R (1989) The order Chroococcales. In: Staley JT, Bryant MP, Pfenning N, Holt JG (eds) Bergey's manual of systematic bacteriology, Vol 3. Williams \& Wilkins, Baltimore, MD, p 1728-1746

$>$ Waterbury JB, Willey JM (1988) Isolation and growth of marine planktonic cyanobacteria. Methods Enzymol 167: 100-105

Webb EA, Ehrenreich IM, Brown SL, Valois FW, Waterbury JB (2009) Phenotypic and genotypic characterization of multiple strains of the diazotrophic cyanobacterium Crocosphaera watsonii, isolated from the open ocean. Environ Microbiol 11:338-348

Submitted: September 17, 2009; Accepted: January 24, 2010 Proofs received from author(s): April 4, 2010 